\title{
Analisis Efisiensi Saluran Pemasaran Ikan Nila di Desa Kupang Kecamatan Lampihong Kabupaten Balangan (Studi Kasus Pada Kelompok Perikanan Kupang Maju)
}

\section{(Efficiency Analysis of Tilapia Marketing Channels in Kupang Village, Lampihong District, Balangan Regency (Case Study on Kupang Maju Fisheries Group))}

\author{
Meldasari'), Ahmad Suhaimi' $^{2)}$, \& Rachman Fitrianoor ${ }^{3)}$ \\ Program Studi Agribisnis Sekolah Tinggi Ilmu Pertanian Amuntai \\ ${ }^{1)}$ Meldasari922@gmail.com \\ 2)ahmad99ec@gmail.com \\ ${ }^{3)}$ rafi@yahoo.com
}

\begin{abstract}
ABSTRAK
Penelitian ini bertujuan mengetahui saluran pemasaran dan lembaga-lembaga yang terlibat dalam pemasaran ikan nila di Desa Kupang Kecamatan Lampihong Kabupaten Balangan, mengetahui struktur pasar ikan nila, menganalisis biaya, keuntungan, marjin pamasaran dan bagian harga yang diterima produsen. Penelitian ini di lakukan secara sengaja dengan metode sensus dan desain penelitian studi kasus serta pengumpulan data dengan wawancara. Hasil penelitian menunjukkan empat saluran pemasaran ikan nila yaitu I : pembudidaya dan pedagang pengumpul, II : pembudidaya, pedagang pengumpul dan pedagang pengecer, III : pembudidaya, pedagang pengumpul dan pedagang besar dan IV : pembudidaya, pedagang pengumpul, pedagang besar dan pedagang pengecer. Struktur pasar adalah persaingan monolistik. Total marjin pemasaran saluran I Rp11.000 per kg, bagian harga yang diterima petani 67,64\%, biaya pemasaran $R p 1.335$ per $\mathrm{kg}$ dan keuntungan yang diterima $\mathrm{Rp} 9.665$ per $\mathrm{kg}$; total marjin pemasaran saluran II Rp 17.000 per $\mathrm{kg}$, bagian harga yang diterima petani 57,5\%, biaya pemasaran Rp $3.785 \mathrm{per} \mathrm{kg}$ dan keuntungan yang di terima 13.215 per kg; total marjin pemasaran saluran III Rp 17.500 per kg, bagian harga yang diterima petani 56,79\%, biaya pemasaran $\mathrm{Rp} 3.192 .5 \mathrm{per} \mathrm{kg}$ dan keuntungan yang diterima $\mathrm{Rp}$ 14.307,5 per $\mathrm{kg}$; total marjin pemasaran saluran IV Rp $15.000 \mathrm{per} \mathrm{kg}$, bagian harga yang diterima petani 60,52\%, biaya pemasaran $\mathrm{Rp} 6.385 \mathrm{per} \mathrm{kg}$, dan keuntungan yang diterima $9.855 \mathrm{per} \mathrm{kg}$. Nilai efisiensi saluran I : 3,92\%, II ; 9,46\%, III : 7,88\% dan saluran IV yaitu 16,80\%. Saluran I yang paling efisien karena lembaga pemasarannya lebih kecil yaitu 3,92\%.
\end{abstract}

Kata Kunci: Saluran, pemasaran, ikan nila, harga, biaya.

\section{ABSTRACT}

This study aims to determine the marketing channels and institutions involved in the marketing of tilapia in Kupang Village, Lampihong Subdistrict, Balangan Regency, to know the structure of the tilapia market, analyze costs, profits, marketing margins and the price portion received by producers. This research was done intentionally by the census method and case study research design and data collection by interview. The results showed four marketing channels for tilapia, namely I: cultivators and collectors, II: cultivators, collectors, and retailers, III: cultivators, collectors and wholesalers and IV: farmers, traders, wholesalers and retailers. Market structure is monolithic competition. The total marketing channel I channel is IDR 11,000 per kg, the portion of the price received by farmers is $67.64 \%$, the marketing cost is IDR 1,335 per kg and the profit gained is IDR 9,665 per kg; channel II's total marketing margin is Rp. 17,000 per $\mathrm{kg}$, the portion of the price received by farmers is $57.5 \%$, the marketing cost is $R p .3,785$ per $\mathrm{kg}$, and the profit received is 13,215 per kg; total channel III marketing margin is Rp. 17,500 per kg, part of the price received by farmers is 56.79\%, marketing costs $R p .3,192.5 \mathrm{per} \mathrm{kg}$ and profits received $\mathrm{Rp}$. 14.307 .5 per $\mathrm{kg}$; total channel IV marketing margin is Rp. 15,000 per $\mathrm{kg}$, part of the price received by farmers is $60.52 \%$, marketing costs $\mathrm{Rp}$. 6,385 per kg and profits received 9,855 per kg. Channel I efficiency value: $3.92 \%$, II; $9.46 \%$, III: $7.88 \%$, and channel IV, which is $16.80 \%$. Channel I is the most efficient because the marketing institution is smaller, namely $3.92 \%$.

Keywords: Channels, marketing, tilapia, prices, costs. 


\section{PENDAHULUAN}

Pembangunan sektor perikanan adalah suatu proses perubahan dan pembaharuan yang berencana menuju tatanan masyarakat, khususnya masyarakat perikanan yang lebih baik. Perikanan mempunyai peranan yang cukup penting, terutama dikaitkan dengan upaya meningkatkan kualitas dan kuantitas produk perikanan, menghasilkan protein hewani dalam rangka memenuhi kebutuhan pangan dan gizi, meningkatkan ekspor, menyediakan bahan baku industri, memperluas lapangan kerja dan kesempatan berusaha, serta mendukung pembangunan wilayah dan tetap memperhatikan kelestarian dan fungsi lingkungan hidup (Setiorini, 2008).

Perikanan meliputi semua kegiatan pada perikanan tangkap dan budidaya secara garis besar, ikan konsumsi dapat dibagi menjadi dua segmen yaitu, bisnis pembenihan dan pembesaran. Kedua segmentasi ini diperlukan dalam masingmasing mempunyai kontribusi yang sama pentingnya dalam menjamin keberlangsungan sistem bisnis ikan konsumsi air tawar. Kedua segmen ini merupakan suatu kesatuan yang masing-masing saling memiliki ketergantungan.

Ikan nila (Oreochromis niloticus) atau disebut tilapia merupakan salah satu ikan air tawar indroduksi yang mempunyai nilai ekonomis yang cukup penting di beberapa daerah di Asia, termasuk Indonesia. Ikan nila didatangkan ke Indonesia pada tahun 1969, perkembangan ikan nila menjadi sangat pesat. Hal ini tersebut tidak lain karena ikan nila mempunyai kemampuan adaptasi yang relatif baik terhadap lingkungan, selain itu ikan nila mudah dipijahkan sehingga mendukung pengembangan budidaya masyarakat (Nugroho, 2013).

Produksi ikan tawar Kecamatan Lampihong Kabupaten Balangan mempunyai produksi budidaya ikan yang cukup kontribusi besar berada di urutan pertama yaitu hasil budidaya sebesar 3.806.637 ton dan 224.394 ton hasil tangkapan dan jumlah total ikan tawar di Kecamatan Lampihong sebesar 4.013.031 ton sedangkan produksi ikan tawar yang terendah berada di Kecamatan Halong yaitu sebesar 80.124 ton hasil budidaya, dan 75.018 ton hasil tangkapan dan jumlah total ikan tawar di Kecamatan Halong sebesar 155.142 ton. Penurunan produksi ikan tawar pada hasil budidaya tahun 2016 dan 2015 di Kabupaten Balangan di sebabkan karena terjadinya musim yang tidak menentu dan pencemaran lahan air sungai yang cukup tercemar. Meskipun terjadi penurunan ikan nila tetap jadi komoditas ikan unggulan yang dirasakan oleh masyarakat karena dapat memberikan keuntungan. Ikan nila merupakan salah satu produksi ikan terbesar dibandingkan dengan ikan lainnya yang berada di kota kabupaten Balangan dengan jumlah produksi yang di hasilkan sebesar 390.221 ton (BPS Kabupaten Balangan, 2017).

Pemasaran ikan di Desa Kupang Kecamatan Lampihong Kabupaten Balangan, ikan nila tidak hanya memenuhi konsumen di Desa Kupang saja, tapi juga memenuhi konsumen ke luar desa. Untuk menjangkau pasar yang lebih luas produsen tidak hanya mengandalkan penjualan kepada konsumen. Maka dari itu pemasaran ikan nila di Desa Kupang Kecamatan Lampihong Kabupaten Balangan memerlukan beberapa lembaga pemasaran agar dapat menyalurkan produk dengan baik dan tepat.

Pemasaran merupakan suatu kegiatan yang diarahkan untuk memenuhi dan memuaskan kebutuhan melaluai proses pertukaran. Setiap produsen selalu berusaha melalui produk yang dihasilkan mendapat tujuan dan sasaran perusahaannya tercapai. Produk yang dihasilkan dapat terjual atau dibeli oleh konsumaen akhir dengan tingkat harga yang memberikan keuntungan perusahan jangka panjang (Assauri, 2013).

Saluran pemasaran merupakan serangkaian organisasi organisasi yang saling tergantung dan terlibat dalam proses menjadikan suatu produk siap untuk dikonsumsi. Saluran pemasaran dapat dibedakan menurut jumlah dan tingkatannya (panjang dan pendek saluran pemasaran). Saluran pemasaran tersebut dipengaruhi oleh skala produksi dari produk yang pasarkan (Domiah, 2016). 
Selama ini pembudidaya/produsen ikan nila tidak mengatahui secara pasti berapa keuntungan yang di dapat setiap penjualan ikan nila, terjadinya tawar menawar yang kuat diantara pedagang perantara akan mempengaruhi marjin ditingkat pedagang perantara dan pembudidaya, yang pada akhirnya akan berpengaruh pada tingkat keuntungan yang diterima oleh pedagang perantara maupun pembudidaya/produsen. Besarnya marjin pemasaran, bagian harga yang diterima pembudidaya/produsen ikan nila atau farmer's share, keuntungan dan biaya akan menentukan efisiensi pemasaran ikan nila, oleh karena itu, diperlukan penelitian untuk mengamati efisiensi saluran pemasaran ikan nila pada kelompok perikanan "Kupang Maju" di Desa Kupang Kecamatan Lampihong Kabupaten Balangan.

Tujuan penelitian ini adalah menganalisis saluran pemasaran serta lembaga pemasaran yang terlibat dan struktur pasar ikan nila pada kelompok perikanan "Kupang Maju" Kecamatan Lampihong, (ii) mengetahui berapa besar margin pemasaran, bagian harga yang diterima pembudidaya/produsen ikan nila (farmer's share), keuntungan dan biaya yang diterima setiap lembaga pemasaran ikan nila pada kelompok perikanan "Kupang Maju" Kecamatan Lampihong dan mengetahui berapa besar tingkat efisiensi pemasaran ikan nila pada kelompok perikanan "Kupang Maju” Kecamatan Lampihong.

\section{METODOLOGI PENELITIAN}

Penelitian ini dilaksanakan pada kelompok perikanan ikan nila "Kupang Maju" yang ketuai oleh Bapak Muhammad Irwannor di Desa Kupang Kecamatan Lampihong Kabupaten Balangan. Waktu penelitian ini direncanakan mulai bulan Maret sampai bulan Juli 2018.Jenis sumber data yang digunakan adalah data primer dan data sekunder. Data primer diperoleh dengan cara wawancara langsung dengan respoden perikanan ikan nila dengan menggunakan pertanyaan dan daftar pertanyaan yang sudah disiapkan sebelumnya. Sedangkan data sekunder diperoleh dari dinas, studi literatur berbagai buku, skripsi, internet dan instansi lainnya yang terkait dengan penelitian ini.

Jenis penelitian yang digunakan penelitian ini adalah jenis penelitian deskriptif kuantatif. Deskriptif kuantitaf adalah penelitian yang bertujuan menjelaskan fenomena fenomena yang ada dengan menggunakan angka-angka untuk mencadarkan/menggambarkan karateristik individu atau kelompok (Syamsudin \& Damayanti, 2011).

Metode pengambilan data penelitian yang digunakan adalah metode sensus dengan jumlah kelompok perikanan "Kupang Maju" sebanyak 19 orang, pemilihan tempat penelitian ini dilakukan secara sengaja (purvosive) penelitian ini dilakukan dengan teknik wawancara, observasi, dan pencatatan secara Snowbal ke setiap responden .

\section{Analisis Data}

Setelah semua data dikumpulkan baik itu data primer maupun sekunder, kemudian data tersebut dianalisis untuk menjawab tujuan penelitian. Analisis dilakukan dengan mengadakan, saluran pemasaran, struktur pasar, marjin pemasaran, bagian haraga yang diterima pembudidaya/produsen (farmer's share), keuntungan dan biaya, efisiensi pemasaran.

Untuk menjawab tujuan pertama yakni saluran pemasaran, struktur pasar dan lembaga pemasaran ikan nila digunakan dengan analisis deskriptif dengan cara menelusuri tiap tiap lembaga pemasaran yang terlibat di dalamnya. Menjawab tujuan kedua yaitu marjin pemasaran dapat dirumuskan menurut Hanafie, (2010) sebagai berikut:

$$
\mathrm{M}=\mathrm{Pr}-\mathrm{Pf}
$$

Keterangan:

$$
\text { MP : Marjin Pemasaran (Rp) }
$$

Pr : Harga di tingkat pengecer (Rp)

Pf : Harga di tingkat petani $(\mathrm{Rp})$

Marjin pemasaran dapat pula diperoleh dengan menjumlahkan keuntungan lembaga pemasaran dengan biaya yang dikeluarkan, secara metamatis dapat ditulis sebagai berikut:

\section{Keterangan:}

$$
\mathrm{M}=\Pi+\mathrm{CM}
$$
M : Marjin pemasaran
$\Pi$ : Keuntungan lembaga pemasaran
$\mathrm{CM}$ : Biaya yang dikeluarkan oleh 
lembaga pemasaran

Besarnya share harga yang diterima produsen (Sp) dari harga yang dibayarkan konsumen dapat dihitung dengan menggunakan rumus (Rahim, 2007), sebagai berikut:

$S p=\frac{P f}{P r} \times 100 \%$

Keterangan:

Sp : Bagian (share) yang di terima petani $(\%)$

Pf : Harga di tingkat petani (Rp)

Pr : Harga di tingkat konsumen akhir atau harga di tingkat pengecer ( $\mathrm{Rp})$

Share keuntungan yang diterima masing-masing lembaga pemasaran digunakan dengan rumus (Hasanah, 2010) sebagai berikut:

Keterangan:

$$
K p=K p^{1}+K p^{2}+K p^{3} \ldots \ldots K p^{n}
$$

Kp : Keuntungan pemasaran

$K p=K p^{1}+K p^{2}+K p^{3} \ldots \ldots K p^{n} \quad: \quad K e u n t u n g a n$ pemasaran tiap lembaga pemasaran

Biaya pemasaran adalah biaya yang dikeluarkan untuk memasarkan suatu komoditi dari produsen kepada konsumen dapat digunakan rumus sebagai berikut:

$$
\mathrm{Bp}=\mathrm{Bp}^{1}+\mathrm{Bp}^{2}+\mathrm{Bp}^{3} \ldots \ldots+\mathrm{Bp}^{\mathrm{n}}
$$

Keterangan:

Bp : Biaya pemasaran

$\mathrm{Bp}^{1}+\mathrm{Bp}^{2}+\mathrm{Bp}^{3} \ldots \ldots+\mathrm{Bp}^{\mathrm{n}}$ : Biaya pemasaran tiap lembaga pemasaran

Menjawab tujuan ketiga yaitu menurut pendapat Soekartawi (2002), teknik untuk meningkatkan efisensi pemasaran adalah teknik S-C-P, yaitu struktur pasar, pelaksanan pasar, dan penampilan pasar. Adapun untuk mengatahui efisiensi pemasaran ikan nila dapat dihitung dengan menggunakan rumus sebagai berikut

Biaya Pemasaran

$$
\mathrm{EP}=\mathrm{x} \begin{array}{r}
\quad 100 \% \\
\quad \text { Nilai produk yang dipasarkan }
\end{array}
$$

Keterangan: Jika Ep nilainya rendah $=$ paling efisien

Efisiensi pemasaran akan terjadi jika :

1. Biaya pemasaran dapat ditekan sehingga keuntungan pemasaraan dapat lebih tinggi

2. Persentase perbedaan harga yang dibayarkan konsumen dan produsen tidak terlalu tinggi

3. Tersedianya fasilitas fisik pemasaran dan

Adanya kompetisi pasar yang sehat

Pasar yang tidak efisien akan terjadi jika :

1. Biaya pemasaran semakin besar, dan

2. Nilai produk yang dipasarkan jumlahnya tidak terlalu besar.

\section{HASIL DAN PEMBAHASAN}

\section{Saluran dan Lembaga Pemasaran Ikan Nila pada Kelompok Perikanan Kupang Maju di Desa Kupang}

Berdasarkan hasil penelitian terdapat beberapa pelaku pemasaran yang ikut serta dalam ikan nila, yaitu: pembudidaya atau produsen, pedagang pengecer, pedagang pengumpul, dan pedagang besar. Pola saluran pemasaran ikan nila pada kelompok perikanan Kupang Maju di Desa Kupang menunjukan bahwa terdapat 4 pola saluran pemasaran, yaitu:

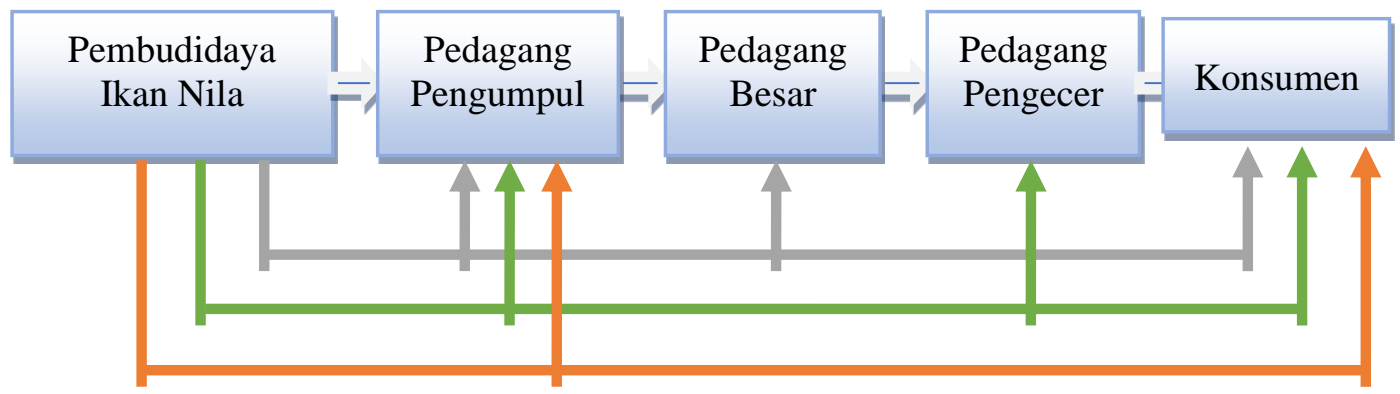


Struktur pasar ikan nila kelompok perikanan Kupang Maju di Desa Kupang yang banyak dijumpai adalah pasar persaingan monopolistik. Hal ini dibebabkan oleh bebarapa hal:

1. Bagian pangsa pasar (market share) yang dimiliki pembudidaya/produsen umumnya sangat kecil, sehingga pembudidaya/produsen dalam pemasaran produk perikanan bertindak sebagai penerimaan harga

2. Produk perikanan pada umumnya diproduksi/dipanen secara masal dan homogen, sehingga apabila pembudidaya/produsen menaikkan harga komoditi yang dihasilkan akan menyebabkan konsumen beralih untuk mengkonsumsi komoditi yang dihasilkan pembudidaya/produsen lainnya.

3. Komoditi/ikan nila dihasilkan mudah mati, sehingga harus secepatnya dijual tanpa memperhitungkan biaya.

4. Pembudidaya/produsen kekurangan harga dan kualitas serta kualitas yang diinginkan konsumen, sehingga pembudidaya/produsen mudah diperdaya lembaga-lembaga pemasaran yang berhubungan dengan pembudidaya/produsen langsung.

5. Adanya kredit dan pinjaman dari lembaga kepada pembudidaya/produsen yang bersifat mengikat.

\section{Biaya, Marjin, Keuntungan Pemasaran dan Farmer's Share}

Upaya untuk memenuhi kebutuhan konsumen terdapat beberapa saluran pemasaran, proses penyaluran barang dari pembudidaya/produsen sampai ke konsumen akhir memerlukan biaya, dengan adanya biaya pemasaran maka suatu produk akan lebih tinggi harganya. Semakin panjang rantai pemasaran maka biaya yang dikeluarkan dalam pemasaran akan semakin meningkat. Berikut ini rata-rata biaya, keuntungan dan marjin pemasaran pada kelompok perikanan ikan nila Kupang Maju di Desa Kupang pada saluran I.

Tabel 1. Rata-rata biaya, marjin dan keuntungan pemasaran pada saluran I

\begin{tabular}{clc}
\hline No. & \multicolumn{1}{c}{ Uraian } & $\mathrm{Rp} / \mathrm{Kg}$ \\
\hline 1. & Pembudidaya/produsen & \\
& Harga Jual & 23.000 \\
2. & Pedagang pengumpul & \\
& Harga beli & 23.000 \\
& Harga Jual & 34.000 \\
Biaya pemasaran & 1.335 \\
Marjin & 11.000 \\
Keuntungan & 9.665 \\
Total marjin & 11.000 \\
Total keuntungan & 9.665 \\
& Farmer's share\% & 67,64 \\
\hline
\end{tabular}

Sumber: Hasil pengolahan data primer (2018).

Berikut ini rata-rata biaya, marjin dan keuntungan pemasaran pada kelompok perikanan ikan nila Kupang Maju di Desa Kupang pada saluran II.

Tabel 2. Rata-rata biaya, marjin dan keuntungan pemasaran pada saluran II

\begin{tabular}{clc}
\hline No. & \multicolumn{1}{c}{ Uraian } & $\mathrm{Rp} / \mathrm{Kg}$ \\
\hline 1. & $\begin{array}{l}\text { Pembudidaya/produsen } \\
\text { Harga Jual }\end{array}$ & 23.000 \\
2. & $\begin{array}{l}\text { Pedagang pengumpul } \\
\text { Harga beli }\end{array}$ & 23.000
\end{tabular}


Harga Jual

Biaya transportasi

Biaya terminal

Marjin

Keuntungan

3. Pedagang pengecer

Harga beli

Harga Jual

Biaya transportasi

Biaya terminal

Marjin

Keuntungan

Total marjin

Total keuntungan

Farmer's share \%
32.000

100

1.695

9.000

7.205

32.000

40.000

917

1.073

8.000

6.010

17.000

13.215

57,5

Sumber: Hasil pengolahan data primer (2018).

Berikut ini rata-rata biaya, marjin dan

perikanan ikan nila Kupang Maju di Desa keuntungan pemasaran pada kelompok Kupang pada saluran III.

Tabel 3. Rata-rata biaya, marjin dan keuntungan pemasaran pada saluran III

\begin{tabular}{clc}
\hline No. & \multicolumn{1}{c}{ Uraian } & $\mathrm{Rp} / \mathrm{Kg}$ \\
\hline 2. & Pembudidaya/produsen & \\
& Harga Jual & 23.000 \\
& Pedagang pengumpul & \\
& Harga beli & 23.000 \\
& Harga Jual & 31.500 \\
& Biaya transportasi & 50 \\
& Biaya terminal & 1.095 \\
& Biaya diskon & 500 \\
& Marjin & 8.500 \\
Keuntungan & 6.855 \\
& Pedagang besar & \\
& Harga beli & 31.500 \\
& Harga jual & 40.500 \\
& Biaya transportasi & 200 \\
& Biaya terminal & 847,5 \\
& Biaya diskon & 500 \\
& Marjin & 9.000 \\
& Keuntungan & 7.453 \\
& Total marjin & 17.500 \\
Total keuntungan & $14.307,5$ \\
& Farmer's share\% & 56,79 \\
\hline
\end{tabular}

Sumber: Hasil pengolahan data primer (2018).

Berikut ini rata-rata biaya, keuntungan dan marjin pemasaran pada kelompok perikanan ikan nila Kupang Maju di Desa Kupang pada saluran IV. 
Meldasari, Ahmad Suhaimi \& Rachman F., Analisis efesiensi saluran pemasaran..

Tabel 4. Rata-rata biaya, marjin dan keuntungan pemasaran pada saluran IV

\begin{tabular}{|c|c|c|}
\hline No. & Uraian & $\mathrm{Rp} / \mathrm{kg}$ \\
\hline \multirow[t]{2}{*}{1.} & Pembudidaya/produsen & \\
\hline & Harga jual & 23.000 \\
\hline \multirow[t]{8}{*}{2.} & Pedagang pengumpul & \\
\hline & Harga beli & 23.000 \\
\hline & Harga jual & 32.000 \\
\hline & Biaya transportasi & 100 \\
\hline & Biaya terminal & 1.220 \\
\hline & Biaya diskon & 2.000 \\
\hline & Marjin & 9.000 \\
\hline & Keuntungan & 5.680 \\
\hline \multirow[t]{7}{*}{3.} & Pedagang besar & \\
\hline & Harga beli & 32.000 \\
\hline & Harga jual & 33.000 \\
\hline & Biaya transportasi & 250 \\
\hline & Biaya terminal & 1.370 \\
\hline & Marjin & 1.000 \\
\hline & Keuntungan & 620 \\
\hline \multirow[t]{10}{*}{4.} & Pedagang pengecer & \\
\hline & Harga beli & 33.000 \\
\hline & Harga jual & 38.000 \\
\hline & Biaya transportasi & 350 \\
\hline & Biaya terminal & 1.095 \\
\hline & Marjin & 5.000 \\
\hline & Keuntungan & 3.555 \\
\hline & Total marjin & 15.000 \\
\hline & Total keuntungan & 9.855 \\
\hline & Farmer's share $\%$ & 60,52 \\
\hline
\end{tabular}

Sumber: Hasil pengolahan data primer (2018).

Efisiensi Pemasaran

Tingkat efisiensi pemasaran ikan nila pada kelompok perikanan Kupang Maju dapat dihitung dengan ratio biaya pemasaran dibagi dengan nilai produk yang di pasarkan kemudian di kalikan $100 \%$.

Tabel 5. Efisiensi pemasaran ikan nila pada masing-masing saluran.

\begin{tabular}{clccc}
\hline No. & $\begin{array}{c}\text { Saluran } \\
\text { Pemasaran }\end{array}$ & $\begin{array}{c}\text { Biaya Pemasaran } \\
(\mathrm{Rp} / \mathrm{Kg})\end{array}$ & $\begin{array}{c}\text { Nilai Akhir Ikan } \\
\text { Nila }(\mathrm{Rp} / \mathrm{Kg})\end{array}$ & $\begin{array}{c}\text { Efisiensi Pemasaran } \\
(\%)\end{array}$ \\
\hline 1. & Saluran I & 1.335 & 34.000 & 3,92 \\
2. & Saluran II & 3.785 & 40.000 & 9,46 \\
3. & Saluran III & $3.192,5$ & 40.500 & 7,88 \\
4. & Saluran IV & 6.385 & 38.000 & 16,80 \\
\hline
\end{tabular}

Sumber: Hasil pengolahan data primer (2018).

Berdasarkan tabel di atas dapat diketahui bahwa efisiensi pemasaran saluran I yaitu $3,92 \%$, saluran pemasaran II yaitu $9,46 \%$, saluran pemasaran III yaitu $7,88 \%$ dan saluran pemasaran IV yaitu $16,80 \%$. Dimana dari hasil tersebut menunjukkan bahwa 
saluran pemasaran I yang paling efisien karena lembaga pemasarannya lebih kecil yaitu $3,92 \%$. Hal ini terjadi karena biaya pemasaran yang dikeluarkan oleh saluran pemasaran I lebih sedikit.

Nilai perbandingan dengan harga pada saluran I lebih kecil bila dibandingkan dengan saluran II, III dan IV, nilai efisiensi pada saluran IV lebih besar bila dibandingkan dengan saluran I, II dan III. Hal tersebut dikarenakan biaya pemasaran pada saluran II, III dan IV lebih besar dibandingkan dengan saluran I.

\section{Saluran pemasaran}

Hasil penelitian Analisis Efisiensi Saluran Pemasaran Ikan Nila pada Kelompok Perikanan Kupang Maju terdapat IV (empat) pola saluran pemasaran. Lembaga pemasaran yang berperan dalam penyampaian ikan nila dari produsen hingga ke konsumen akhir adalah seperti pedagang pengumpul, pedagang besar, dan pedagang pengecer.

\section{Identifikasi Struktur Pasar}

Berdasarkan hasil penelitian identifikasi struktur pasar pada kelompok perikanan Kupang Maju adalah pasar persaingan monopolistik, struktur pasar dalam makna sederhana dapat diartikan sebagai sifat atau karakteristik pasar. Faktor penentu karakteristik struktur pasar yaitu, jumlah pembeli dan penjual, kondisi atau keadaan produk, kondisi keluar atau masuknya pasar, tingkat pengetahuan informasi pasar yang dimiliki pertisipan dalam pemasaran.

\section{Biaya Pemasaran}

Hasil penelitian total biaya pemasaran terbesar adalah $\mathrm{Rp} 6.385$ pada saluran IV (dengan diikuti harga jual yang tinggi), berbeda dengan total biaya pada saluran III sebesar Rp 3.192,5 per kg, saluran II sebesar Rp 3.785 per kg, saluran I sebesar Rp 1.335 per kg. Besarnya biaya pemasaran dipengaruhi lokasi pemasaran yang berbeda, dan efektifitas pemasaran yang dilakukan (biaya pemasaran terdiri dari biaya transportasi, upah tenaga kerja, biaya kemasan, biaya oksigen, biaya es batu dan biaya diskon). Artinya semakin banyak biaya yang dikeluarkan maka harga jual semakin tinggi, hal itu untuk menutupi biayabiaya yang dikeluarkan dan mendapat keuntungan yang maksimal

\section{Marjin Pemasaran}

Hasil penelitian menunjukkan total margin pemasaran saluran I adalah sebesar Rp 9.000 per kg, saluran II sebesar Rp 17.000 per kg, saluran III sebesar Rp 17.500 per kg, saluran IV sebesar Ro 15.000 per kg. Dilihat dari hasil tersebut total marjin pemasaran terkecil adalah pada saluran I sebesar Rp 9.000 per kg, karena pada saluran I pedagang pengumpul menjual ikan nila langsung kepada konsumen dengan jumlah yang di inginkan konsumen, hal tersebut di sebabkan adanya perbedaan antara harga yang dibayarkan konsumen dengan harga yang diterima pembudidaya/produsen.

\section{Keuntungan Pemasaran}

Total keuntungan yang diperoleh dari hasil penelitian usaha pemasaran ikan nila pada saluran I sebesar Rp 9.905,57 per kg, saluran II sebesar Rp 13.215 per kg, saluran III sebesar Rp14.307,5 per kg, saluran IV sebesar Rp 9.855 per kg. Total keuntungan pemasaran terbesar adalah pada saluran III yaitu Rp 14.307,5. Hal ini di sebabkan karena adanya perbedaan jarak dari produsen ke konsumen, besarnya keuntungan diketahui dari perbedaan selisih harga jual, harga beli dan biaya pemasaran, masingmasing lembaga pemasaran tersebut akan menentukan keuntungan yang diambil sesuai dengan biaya yang dikeluarkan untuk proses pemasaran.

\section{Farmer's Share}

Farmer's share atau bagaian harga yang diterima pembudidaya dapat diketahui pada saluran I sebesar $67,64 \%$, saluran II sebesar 57,5 \%, saluran III sebesar 56,79\%, saluran IV sebesar 60,52 \%. Rendahnya share yang diterima oleh pembudidaya/produsen pada saluran III jika dibandingkan dengan saluran II, IV dan I disebabkan karena biaya operasional yang digunakan cukup besar seperti biaya operasional bensin dan dan lain-lain.. 
Saluran pemasaran ikan nila pada kelompok perikanan Kupang Maju di Desa Kupang terdiri dari IV saluran pemasaran. Struktur pasar ikan nila pada kolompok perikanan Kupang Maju di Desa Kupang yang banyak dijumpai adalah pasar persaingan monopolistik.

Berdasarkan ke empat saluran yang ada dalam pemasaran ikan nila tersebut maka dapat diketahui marjin pemasaran, bagian harga yang diterima pembudidaya, biaya pemasaran dan keuntungan yang diterima setiap lembaga pemasaran. Saluran pemasaran I yang paling efisien karena lembaga pemasarannya lebih kecil yaitu $3,92 \%$. Hal ini terjadi karena biaya pemasaran yang dikeluarkan oleh saluran pemasaran I lebih kecil.

\section{DAFTAR PUSTAKA}

Assauri, S. 2013. Manajemen Pemasaran. PT.Raja Grafindo Persada. Jakarta.

BPS Kabupaten Balangan. 2017. Data Produksi Ikan Tawar 2017. BPS Kabupaten Balangan.

Domiah, A. 2016. Analisis Saluran dan Efisiensi Pemasaran Industri
Perikanan Tangkap Tuna Skala Kecil di Kota Bitung. Skripsi. Program Studi Agribisnis Fakultas Pertanian Universitas Jember.

Hanafie, R. 2010. Pengantar Ekonomi Pertanian. Andi Offset. Yogyakarta.

Nugroho, E. 2013. Nila Unggul \#1. Penebar Swadaya. Jakarta.

Rahim, A. Hastuti, D. 2007. Ekonomika Pertanian. Penebar Swadaya. Jakarta.

Soekartawi. 2002. Prinsip Dasar Manajemen Pemasaran Hasil-Hasil Pertanian. PT Raja Grafindo Persada. Jakarta.

Setiorini, F. 2008. Analisis efisiensi pemasaran ikan nila di Kabupaten Tanggamus Kecamatan Pagelaran. Skripsi. Program Studi Manajemen Bisnis Dan Ekonomi Perikanan Kelautan Fakultas Perikanan Dan Ilmu Kelautan Institut Pertanian Bogor.

Syamsuddin dan Damayanti. 2011. Metode Penelitian Pendidikan Bahasa. Remaja Rosdakarya. Bandung. 